\title{
PENGEMBANGAN OBJEK WISATA DANAU KEMBAR DI KABUPATEN SOLOK
}

\author{
Oleh \\ Risnawati Fitri \\ Program Studi Pendidikan geografi STKIP PGRI Sumatera Barat \\ fitririsnawati@gmail.com
}

\begin{abstract}
This study aims to describe the development of tourism object in Solok District, espescially in terms of of cleanliness, safety, the arrangement of which less attention, as well as facilities and infrastructure are still lacking, so that yet provide maximum results. Type of this research is qualitative, data sources used are the words and actions that come from people who know the problems of research. The subject of this research is Department of Tourism, Subdistract, Tourism Manager, Public, and the Visitors of this tourism object. The research subject collecting by purposive sampling technique. Data collection technique done by the interviews, observation and picture taking. Data analysis techniques are reduction data, data display and interpretation of data. Data validity testing techniques in use extension of participation, perseverance, observation. Results of the study explained that : 1) The condition of the existing infrastructure and facilities in this tourism object is still not complete. 2) The barriers development of this tourism object is visible from the road condition are not maintained, The security, the orderliness and the cleanliness arestall low. 3) in an effort to develop tourism object, it need an corporation from all related side like department of tourism, Subdistract, the manager and the society to help each other in keep the road is clean, keep it the safe, and fix the facilities and infrastructure.

Keywords: Development Of Tourism, Danau Kembar, Infrastructure
\end{abstract}

\section{PENDAHULUAN}

Peranan lingkungan bagi kelangsungan hidup manusia umumnya dan bangsa Indonesia khususnya sangat besar terutama bagi kelangsungan dan pembangunan mencapai masyarakat adil dan makmur. Oleh sebab itu pembangunan pada sektor lingkungan perlu dilakukan secara berkelanjutan melalui tahapan-tahapan yang jelas, salah satu pembangunan yang berhubungan dengan aspek lingkungan adalah pembangunan sektor pariwisata.

Propinsi Sumatera Barat merupakan daerah tujuan wisata yang menjadi andalan Indonesia. Pemerintah telah menetapkan Sumatera Barat sebagai salah satu daerah tujuan wisata utama di Indonesia. Kekayaan keindahan alamnya dan budayanya memungkinkan Sumatera Barat dikembangkan sebagai kawasan wisata. Di sumatera Barat terdapat wisata gunung, danau, sungai dan bahari, Salah satu objek wisata yang paling menarik adalah objek wisata danau atau objek wisata air tawar. 
Beberapa objek wisata danau air tawar seperti di Sumatera Barat adalah Danau Singkarak, Danau Maninjau dan Danau Diatas serta Danau Dibawah atau lebih dikenal dengan sebutan Danau Kembar. Danau Kembar merupakan danau vulkanik yang terletaknya berdampingan dan dipisahkan oleh sebuah bukit yang menjulang diantara keduanya. Keindahan danau ini bisa kita saksikan ketika mulai memasuki daerah panorama danau dibawah.

Karakteristik Danau Kembar sebagai salah satu objek wisata di Sumatera Barat merupakan salah satu daerah tujuan wisata yang menyajikan keindahan alam. Danau ini terletak $56 \mathrm{~km}$ dari kota Padang dengan ketinggian $1600 \mathrm{~m}$ diatas permukaan laut. Kegiatan yang dapat dilakukan pada kawasan objek wisata ini cukup banyak selain kegiatan memancing, naik boat kedaerah seberangnya serta ditunjang dengan pemandangan alam yang indah dan menghijau disekeliling danau, juga berupa aktifitas taman bermain, tempat camping atau berkemah, dan lain sebagainya..

Berdasarkan hasil observasi sementara yang peneliti lakukan di objek wisata Danau Kembar, bahwa objek wisata ini belum ada peningkatan pengembangan yang baik, terutama dari kebersihan, keamanan, penataan yang kurang diperhatikan serta sarana dan prasarana yang masih kurang, sehingga belum memberikan hasil yang maksimal, maka untuk itu perlu dikelola secara baik. Dan berdasarkan hasil observasi awal tentang pengelolaan objek wisata danau kembar ini berbeda, Danau diatas dikelola oleh pemerintah sedangkan danau dibawah dikelola oleh nagari itu sendiri, Studi tentang pengembangan objek wisata ini perlu supaya kebersihan, keamanan, penyediaan sarana dan prasarana dapat ditingkatkan. Selanjutnya adanya keterpaduan antara pihak-pihak yang berkepentingan baik dikalangan pemerintah maupun swasta.

Berangkat dari berbagai permasalahan diatas maka penulis tertarik untuk mengadakan penelitian dengan judul "Pengembangan Objek Wisata Danau Kembar di Kabupaten Solok". 


\section{METODOLOGI}

Jenis penelitian ini adalah penelitian kualitatif. Penelitian ini berusaha untuk mengungkapkan data secara ilmiah yaitu untuk menjawab masalah yang telah di rumuskan . Penelitian ini menjalani langkah-langkah serta proses untuk sampai pada suatu kesimpulan. artinya mencari informan sebanyak mungkin melalui informan dan pengamat di lapangan.

Penelitian ini dilakukan di objek wisata danau kembar di Kabupaten Solok, pemilihan sampel ini menggunakan metode purposive sampling (penunjukan) yaitu penelitian sampel berdasarkan karakteristik tertentu.

Menurut Moleong (2010:132) Informan adalah orang yang di manfaatkan untuk memberikan informasi tentang situasi dan kondisi latar penelitian. Dalam penelitian ini sebagai informan adalah staf dinas pariwisata Kabupaten Solok, pengelola objek wisata Danau Kembar, Camat Danau Kembar, wisatawan yang berkunjung, masyarakat yang tinggal di sekitar objek wisata Danau Kembar yang dapat memberikan informasi yang dibutuhkan.

\section{PEMBAHASAN}

Pertama: Kondisi sarana dan prasarana berdasarkan hasil wawancara peneliti dengan informan dilapangan ditemukan bahwa sarana dan prasarana yang ada di objek wisata danau diatas ini masih belum maksimal dan lengkap, dan begitupun dengan objek wisata danau dibawah masih belum lengkap salah satunya permainan untuk anak-anak masih kurang, sedangkan untuk objek wisata danau diatas seperti alat untuk permainan air (boat) tidak ada sama sekali. Diharapkan Pemerintah dapat memberikan anggaran dana untuk memperbaiki dan menambah sarana dan prasarana yang masih belum lengkap supaya objek wisata danau kembar ini dapat hidup dan berkembang lebih baik lagi.

Sarana kepariwisataan adalah perusahaan-perusahaan yang memberikan pelayanan kepada wisatawan, baik secara langsung maupun tidak langsung dan hidup serta kehidupannya banyak tergantung pada kedatangan wisatawan (Muljadi 2012:13). Teori Muljadi untuk penelitian objek wisata danau kembar bisa dikatakan belum berlaku di objek wisata danau kembar seperti pelayanan 
perusahaan-perusahan kepada wisatawan, misalnya agen travel untuk wisatawan supaya mudah berkunjung ke objek wisata belum ada sama sekali.

Sedangkan menurut Suwantoro (2004:21), prasarana wisata adalah sumber daya alam dan sumber daya buatan manusia yang mutlak dibutuhkan oleh wisatawan dalam perjalanannya di daerah tujuan pariwisata, seperti jalan, listrik, air, rumah sakit, telekomunikasi, terminal, jembatan, dan lain sebagainya.

Teori Gamal tentang prasarana ini sudah berlaku di objek wisata danau kembar dan bisa dikatakan sudah sedikit maksimal meskipun masih ada kekurangan-kekurangan yang harus ditambah lagi oleh pemerintah.

Kedua: Hambatan dalam pengembangan objek wisata danau kembar berdasarkan hasil wawancara peneliti dengan pengelola objek wisata dan dengan masyarakat bahwa kondisi jalan merupakan hal terpenting, karena salah satu sarana untuk memperlancar dan mencapai tujuan ke objek wisata danau kembar. Keadaan jalan sekitar objek terutama jalan menuju objek wisata Dermaga Danau Dibawah dan Panorama Danau Dibawah tidak terawat dengan baik, karena jalan yang semulanya bagus dan lebar telah dipenuhi semak belukar dikiri kanan jalan yang mengakibatkan jalan terlihat sempit dan kecil.

Keadaan jalan yang demikian bukan hanya menjadi perhatian dari pihak pemerintah pada saat-saat tertentu saja, hal ini disebabkan anggaran dana untuk perawatan jalan belum memadai. Disamping itu keadaan jalan yang menjadi sempit karena kurangnya kesadaran masyarakat yang mempunyai lokasi ladang disepanjang pinggiran jalan, menumpuk semak-semak yang ada diladang mereka kepinggir jalan yang menyebabkan penyempitan badan jalan, jauh berbeda dengan danau diatas keadaan jalannya sangat bagus dan luas dan tidak berlubang sama sekali.

Selain itu kurangnya keamanan di danau bawah dikarenakan sepanjang yang sudah peneliti amati, keamanan dilokasi objek wisata danau kembar masih kurang hal ini terbukti masih ada pemuda atau pihak yang tidak berwenang melakukan pungutan liar kepada pengunjung, sedangkan didanau diatas bisa dikatakan keamanan dapat terkendali dan jauh dari pungutan liar tersebut. Keadaan ini tentu 
saja menjadikan para pengunjung yang datang ke objek wisata danau dibawah merasa tidak nyaman. ketertiban juga menjadi hambatan dalam pengembangan objek wisata di danau bawah, kurangnya ketertiban dalam berbagai hal diantaranya: belum adanya sarana parkir yang layak digunakan kalaupun sudah ada tapi masih bersifat terbatas dan tidak bisa digunakan oleh pengunjung dengan baik, karena tempat parkir tersebut digunakan oleh masyarakat sekitar untuk membangun lapak-lapak kecil yang mereka gunakan sebagai tempat untuk berjualan. Kondisi seperti ini menyulitkan para pengunjung untuk dapat memarkir kendaraan dengan baik sehingga mereka parkir disembarang tempat berbeda dengan objek wisata danau atas tempat parkir sudah disediakan meskipun tidak begitu luas.

Hambatan yang tidak kalah pentingnya dalam pengembangan objek wisata danau kembar adalah kurangnya kebersihan disekitar lokasi objek wisata terutama sampah dan semak liar yang dibiarkan saja tumbuh, belum ada terlihat upaya untuk membersihkannya. Selain itu kenangan juga merupakan kesan yang didapat oleh seseorang selama berada dilokasi objek wisata danau kembar, namun kenangan yang didapat kurang berkesan yang diakibatkan oleh berbagai masalahmasalah yang terjadi sekarang ini di objek wisata danau kembar mulai dari masalah jalan, keamanan, ketertiban, kebersihan yang masih belum ada peningkatannya sehingga menimbulkan kenangan atau kesan yang kurang baik yang diperoleh wisatawan selama melakukan kunjungan.

Dengan demikian perlu adanya kerja sama samua pihak yang terkait seperti dinas pariwisata, camat, walinagari, pengelola dan masyarakat untuk bekerja sama dalam mengembangkan objek wisata Danau Kembar.

Menurut Bakaruddin (2009:82:83) Wisatawan yang senang akan berkunjung ke suatu tempat apabila merasa aman, tentram, tidak takut. Jadi keamanan yang dimaksud suatu kondisi yang memberikan suasana tentram bagi wisatawan, bebas dari rasa takut dan tidak khawatir akan keselamatan jiwa, raga dan harta milik, bebas dari ancaman gangguan dan tindakan kekerasan. 
Berdasarkan teori Bakaruddin masih kurang berlaku di objek wisata ini karena dilihat dari hambatan yang terjadi masih banyak wisatawan yang belum mendapatkan kenyamanan selama berada diobjek wisata danau kembar.

Ketiga: Upaya dalam pengembangan objek wisata danau kembar adalah untuk meningkatkan pengembangan objek wisata perlu adanya kerja sama dari semua pihak yang terkait seperti dinas pariwisata, camat, walinagari, pengelola dan masyarakat untuk bersama-sama mengembangkannya terutama merawat dan menjaga kebersihan jalan, menjaga keamanan di objek wisata Danau kembar dengan menertibkan pungutun liar, menertibkan bangunan-bangunan liar supaya wisatawan dapat memarkirkan kendaraannya, dan juga menjaga kebersihan disekitar objek wisata serta menciptakan kenangan yang baik yaitu dengan memperbaiki sarana dan prasarana objek wisata, membentuk kelompok sadar wisata dan memberikan penyuluhan kepada masyarakat sekitar.

Menurut Yoeti (1997) dalam (Silvia Sari 2012) menyatakan, dalam pengembangan objek wisata sangat ditentukan oleh kemampuan pihak-pihak pengelola wisata daerah yang bersangkutan. Dengan kata lain berhasil atau tidaknya suatu darah dikembangkan menjadi daerah tujuan wisata ditentukan oleh pihak pengelola dan sikap masyarakat.

Teori ini sudah mulai berjalan di objek wisata danau kembar dan pemerintah maupun pihak yang bersangkutan sedang menjalankan dan mengupayakan pengembangan objek wisata danau kembar kearah yang lebih baik lagi.

\section{KESIMPULAN}

Dari uraian diatas dapat disimpulkan sebagai berikut :

1. Kondisi Sarana dan Prasarana yang ada di objek wisata danau kembar ini masih belum maksimal dan lengkap.

2. Hambatan pengembangan objek wisata Danau Kembar terlihat dari kondisi jalan yang tidak terawat, keamanan yang masih kurang terjaga, kurangnya ketertiban, belum adanya peningkatan kebersihan serta memberikan kenangan yang kurang baik. 
3. Upaya dalam pengembangan objek wisata danau kembar adalah untuk meningkatkan pengembangan objek wisata perlu adanya kerja sama dari semua pihak yang terkait seperti dinas pariwisata, camat, pengelola dan masyarakat untuk bersama-sama mengembangkannya terutama merawat dan menjaga kebersihan jalan, menjaga keamanan di objek wisata Danau kembar dengan menertibkan pungutun liar, menertibkan bangunan-bangunan liar supaya wisatawan dapat memarkirkan kendaraannya, dan juga menjaga kebersihan disekitar objek wisata serta menciptakan kenangan yang baik yaitu dengan memperbaiki sarana dan prasarana objek wisata, membentuk kelompok sadar wisata dan memberikan penyuluhan kepada masyarakat sekitar.

\section{DAFTAR PUSTAKA}

Bakaruddin.2008.Perkembangan danPermasalahan Kepariwisataan.Padang UNP Press.

Moleong.2010.Metodologi Penelitian Kualitatif. Bandung: PT Remaja Rosdakarya.

Muljadi.2012.Kepariwisataan dan Perjalanan. Jakarta: Rajawali Pers.

Sari, Silvia.2012.Objek Wisata Alam Danau Lebar Kecamatan Air Dikit Kabupaten Mukomuko.Skripsi.

Suwantoro, Gamal. 2004. Dasar-Dasar Pariwisata. Yogyakarta: Andi Offset. 